\title{
МОНГОЛ ЧОНОГОНО (JURINEA MONGOLICA MAXIM.) УРГАМЛЫН ФИТОХИМИ БОЛОН БИОЛОГИЙН ИДЭВХИЙН СУДАЛГАА
}

\author{
М. Думаа ${ }^{1 *}$, Т. Солонго ${ }^{1}$, М. Болортуяа ${ }^{1}$, Г. Чүнсриймятав ${ }^{1,2}$, \\ Маргит Грүнер², Ханс-Яаохим Кноелкер ${ }^{2}$, Д. Рэгдэл \\ ${ }^{1}$ Хими, химийн технологийн хүрээлэн, Шинжлэх ухааны Академи, Монгол улс \\ ${ }^{2}$ Хими технологийн тэнхим, Дрездений их сургууль, ХБНГУ \\ Цахим иуудан:dumaa_mishig@yahoo.com
}

\section{Хураангуй}

Монгол чоногоно (Jurinea mongolica Maхim.) ургамльн газрын дээд хэсгийн этилачетатын бүлэг ханднаас хиспидулин бодисыг иээрээр ялгаж, молекульн бүтэи байгууламжийг масс спектрометр, 1 1Н, 13 С болон хоёр хэмжээст иөмийн соронзон резонансын (ЦСР) спектроскопын аргаар таньж тодорхойлов.Тухайн ургамлын нийлбэр алкалоид, хлороформ, этилачетатын хандны бактерийн антибиотикт тэсвэрлэх чадварыг дарангуйлах (guоrum sensing (QS) систем) идэвх нь 30мг/мл тунд $10.0 \pm 0.0$ мм, $15.5 \pm 2.1$ мм, $12.0 \pm 4.24$ мм; хлороформын хандны Staphylococcus aureus (S. aureus), Micrococcus luteus (M. luteus), Sh. Epidermius (Sh. epidermius) бактерийн ургалтыг дарангуйлсан хэмжээ нь 10 мг/мл тундаа 11.4 мм, 13.12 мм, 15.16 мм тус тус байна. Харин тухайн ургамлын мутагенийг дарангуйлах идэвх нь петролейны эфир, хлороформ, этилацетат, н-бутанол, усан үлдэгдэл болон нийлбэр алкалоидод 8\%, 62\%, 46\%, 7\%, 44\%, 59\% тус тус байв. Монгол чоногоно

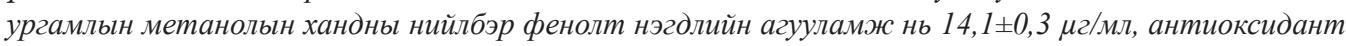

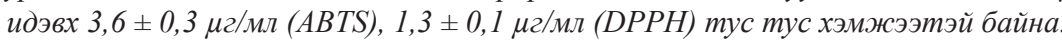

Түлххүр уг: Гиспадулин, gиогит sensing, бактерийн антибиотик тэсвэрлэх чадвар, мутаген, антиоксидант чанар, фенолт нэгдэл

\section{ОРШИЛ}

Монгол оронд Нийлмэл цэцэгтний (Compositae) овгийн 2 зүйл Чоногоно ургадаг. Арзгар жимст чоногоно (Jurinea chaetocarpa Ldb.), Монгол чоногоно (Jurinea mongolica Maxim.). Эдгээрээс Монгол чоногоно нь Их нууруудын хотгор (Хар-ус нуур), Олон нуур, Дорнод говь, Говь-Алтайн ургамал газар зүйн тойрогт цөл, цөлөрхөг хээрийн бүсэд уул толгодын чулуурхаг хажуу, элсэрхэг сайрын хөвөөгөөр ургадаг ${ }^{1}$. Одоогийн байдлаар дэлхий дээр Чоногоны төрлийн 250 зүйл ургамал Төв болон Зүүн өмнөд Ази, Газрын дундад тэнгисийн орчмоор нилээд ихээр тархан ургагадаг болохыг зарим ангилал зүйч эрдэмтэд тодорхойлсон байна ${ }^{2}$. Түүнээс19 зүйл Чоногоно зөвхөн Туркийн нутагт ургадаг ба тэдгээрийн 7 зүйл нь тухайн орны унаган ургамалд багтдаг байна, ${ }^{3,4}$. Ер нь Чоногоны зүйл ургамлын фитохими болон биологийн идэвхийн судалгаа бараг хийгдээгүй байгаа бөгөөд тухайн зүйл ургамлын газрын дээд хэсгээс сесквитерпены лактон ${ }^{5-7}, \mathrm{C}-14, \mathrm{C}-15$ байрлал дээрээ хүчилтөрөгчтэй холбогдсон 
гермакранолид ${ }^{8}$ таван цагирагттритерпеныг зөвхөн гурван зүйл Чоногоноос ялгасан байна ${ }^{9,10}$. Туркийн эрдэмтэн С. Кирбаг, Ф. Зенгин зэрэг эрдэмтэд Jurinea ancyrensis Bornm. ургамлын бактерийн эсрэг идэвхийг тодорхойлсон байна ${ }^{11}$. Энэтхэгийн ардын эмнэлэгт Jurinea dolomiae ургамлыг бэлгийн чадавх хийгээд дархлаа сайжруулахад хэрэглэдэг тухай мэдээлсэн байна ${ }^{12}$. Харин

\section{СУДАЛГААНЫ МАТЕРИАЛ, АРГА ЗУЙ}

Судалгааны материал: Монгол чоногоно (Jurinea mongolica Maxim.) ургамлын газрын дээд хэсгийг 2014 оны 8 сард Дорноговь аймгийн Сайншанд сумын нутаг Ханбаянзүрх уулын хормой, элсэрхэг сайрын хөвөө, нүцгэн толгодоос түүж бэлтгэв. Тухайн ургамлын ангилал зүйн тодорхойлолтыг Ч. Санчир (ШУАийн Ботаникийн хүрээлэн) хийв. Ургамлын хатаадас ШУА-ийн Хими, химийн технологийн хүрээлэнгийн Байгалийн нэгдлийн химийн лабораторид хадгалагдаж байна.

Арга зүй: Монгол чоногоно (Jurinea mongolica Maxim.) ургамлын газрын дээд хэсгийг түүж стандартын дагуу хатааж, нунтаглав. Дээжийг 95\%-ийн этилийн спиртээр перколацийн аргаар хандлав. Хандлагч уусмалыг зайлуулсны дараа өтгөн хандыг нэрмэл усаар сүспензлэн петролейны эфир, хлороформ, этилацетат, н-бутанолоор дараалуулан бүлэг ханд манай оронд ургадаг Монгол чоногоно ургамлын фитохимийн болон биологийн идэвхийн судалгаа огт хийгдээгүй байгаа юм.

Бид энэхүу бүтээлдээ манай орны унаган ургамлаар тодорхойлогдсон Монгол чоногоно ургамлын газрын дээд хэсгийн фитохимийн болон биологийн идэвхийн судалгааг хийхээр зорилго тавьж ажиллав.

гарган авав. Бүлэг ханд бүрт нимгэн үеийн хроматографийн (HYX) судалгаа хийж, хэт ягаан туяаны (ХЯТ) гэрлээр шарж, илрүүлэгч урвалжаар тодруулан дүн шинжилгээ хийв. Улмаар этилацетатын бүлэг хандыг баганат хроматографийн (БХ) аргаар судалж Jm-1 цэвэр бодис ялган авч, түүний молекулын бүтэц байгууламжийг орчин үеийн спектроскопийн аргаар таньж тодорхойлов.

Тухайн ургамлын зарим бүлэг хандны бактерийн антибиотикт тэсвэрлэх чадварыг дарангуйлах идэвхийг (guorum sensing (QS) систем) Ахмедийн ${ }^{13}$ (Ahmed et al., 1998), бактерийн эсрэг идэвхийг цаасан дискийн ${ }^{14,15}$, мутацийн эсрэг идэвхийг Амесийн сорилоор ${ }^{18-20}$ (Ames et. al.,1973), нийлбэр фенолт нэгдлийг Folin- Ciocalteauын аргаaр, чөлөөт радикалыг дарангуйлах идэвхийг ABTS ба DPPH аргуудаар тус тус харьцуулан судлав ${ }^{21-23}$.

\section{СУДАЛГААНЫ АЖЛЫН ҮР ДУН БА ХЭЛЦЭМЖ}

\section{1. Монгол чоногоно (Jurinea mongolica} Maxim.) ургамлын фитохимийн судалгаa

Монгол чоногоно (Jurinea mongolica Maxim.) ургамлын газрын дээд хэсгийг түүж агаар солилцох орчинд хатааж, гадны хольцоос цэвэрлэн бэлтгэв. ИйнхүҮ бэлтгэсэн дээжнээс 600 г-ыг жинлэн авч стандартын дагуу нунтаглаж, 2.7 л 95\%ийн этилийн спиртээр перколацийн аргаар тасалгааны температурт 3 удаа хандлав.
Этилийн спиртийг нам даралтын дор вакум ууршуулагчаар нэрж, 93.34 г өтгөн ханд гарган авав. Өтгөн хандыг нэрмэл усаар сүспензлэн петролейны эфир (5.07 г), хлороформ (1.91 г), этилацетат (2.23 г), н-бутанолоор (6.72 г) дараалуулан хандлав. Үлдэгдэл усан хандыг өтгөрүүлэв (29.96 г). Эдгээрээс этилацетатын хандыг БХ-ын apгаap Sephadex LH-20 маркийн силуфолыг ашиглан $100 \%$ ус; $\mathrm{H}_{2} \mathrm{O}-\mathrm{CH}_{3} \mathrm{OH}$-ын $9: 1 ; 8$ 
$: 2 ; 7: 3 ; 6: 4 ; 5: 5$ системээр дараалуулан угааж 55-62-p фракциас Jm-1 (5.6 мг) бодисыг химийн цэвэр төлөв байдлаар ялгав. Jm-1 бодис нь шар өнгөтэй нунтаг бөгөөд метанолд сайн уусна, хлороформд уусахгүй.Тухайн бодисын масс нь ESIMS m/z: $301.25[\mathrm{M}+\mathrm{H}]^{+}$байсан ба түүний устөрөгчийн болон нүүрстөрөнчийн атомын тоо, тэдгээрийн харилцан үйлчлэлийг тогтоох зорилгоор түүнийг метанолд (MeOD) уусгаж Bruker Avance $600 \mathrm{MHz}$ багаж дээр ${ }^{1} \mathrm{H}$ ПСР ба ${ }^{13} \mathrm{C}$, ЦСРын спектрыг бүртгэсэн дүнг Хүснэгт 1.энд үзүҮлэв.

Хүснэгт 1. Јт-1 бодисын ${ }^{1} Н$ ПСР ба ${ }^{13}$ С ЦСР-ын спектрын дүн, бо0МГи, МеОD

\begin{tabular}{|c|c|c|c|c|}
\hline № & Н-атом & $\begin{array}{c}\text { Хими шилжилтын утга } \\
\text { (бс.х., мульт. чанар, ССХY Гц) }\end{array}$ & С-атом & $(\boldsymbol{\delta}$ c.x. $)$ \\
\hline 1 & - & - & - & - \\
\hline 2 & - & - & $\mathrm{C}-2$ & $166(\mathrm{C})$ \\
\hline 3 & H-3 & $6.57(1 \mathrm{H}, \mathrm{s}, \mathrm{H}-3)$ & $\mathrm{C}-3$ & $103(\mathrm{CH})$ \\
\hline 4 & - & - & $\mathrm{C}-4$ & $183.5(\mathrm{CO})$ \\
\hline 5 & OH & $13.01(1 \mathrm{H}, \mathrm{s})$ & $\mathrm{C}-5$ & $164(\mathrm{C})$ \\
\hline 6 & - & - & $\mathrm{C}-6$ & $134.3(\mathrm{C})$ \\
\hline 7 & $\mathrm{OH}$ & - & $\mathrm{C}-7$ & $156(\mathrm{C})$ \\
\hline 8 & H-8 & $6.50(1 \mathrm{H}, \mathrm{s}, \mathrm{H}-8)$ & $\mathrm{C}-8$ & $97(\mathrm{CH})$ \\
\hline 9 & - & - & C-9 & $154(\mathrm{C})$ \\
\hline 10 & - & - & $\mathrm{C}-10$ & $105(\mathrm{C})$ \\
\hline 11 & - & - & $\mathrm{C}-1^{\prime}$ & $124(\mathrm{C})$ \\
\hline 12 & H-2' & $7.90(2 \mathrm{H}, \mathrm{d}, \mathrm{J}=8.6$ Гц, H-2', H-6') & C-2' & $129.2(\mathrm{CH})$ \\
\hline 13 & H-3, & 6.95 (2H, d, J=8.6 Гц, Н-3', H-5') & C-3' & $108(\mathrm{CH})$ \\
\hline \multirow[t]{2}{*}{14} & - & - & C-4' & $162.5(\mathrm{C})$ \\
\hline & & - & $\mathrm{C}-5$ & $108(\mathrm{CH})$ \\
\hline 16 & & - & C-6' & $129.2(\mathrm{CH})$ \\
\hline 17 & $-\mathrm{CH}_{3}$ & $3.92\left(3 \mathrm{H}, \mathrm{s}, \mathrm{OCH}_{3}\right)$ & $-\mathrm{OCH}_{3}$ & 60.8 \\
\hline
\end{tabular}

${ }^{1} \mathrm{H}$ ПСР-ын спектрийн судалгааны дүнд $\delta 13.01-3.92$ саяны хэсгийн (с.х.) химийн шилжилтийн утганд нийтдээ 12 устөрөгчийн атомын сигнал илэрсэн. Эдгээр устөрөгчийн атомын сигналуудыг түүний мультиплит чанар, спин, спины харилцан үйлчлэлийн (ССХY) тогтмолыг харгалзан дүн шинжилгээ хийх замаар тэдгээрийн байрлалыг тогтоов.

$\begin{array}{lllllll}\delta & 6.57 & \text { ба } & \delta & 6.50 & \text { с.х.-ийн химийн }\end{array}$ шилжилтийн утганд тус бүр 1 протоны идэвхтэй 2 синглет сигнал илэрснийг Н-3, Н-8 байрлалд, $\delta 7.90$ ба $\delta 6.95$ с.х.-ийн химийн шилжилтийн утганд тус бүр 2 протоны идэвхтэй, 8.6 Гц-ийн ССХY-ийн тогтмолтой 2 дублет сигнал илэрснийг
Н-2', Н-6' ба Н3', Н-5' байрлалуудад тус тус оноосон. Харин $\delta 3.92$ c.х.-ийн химийн шилжилтийн утганд 3 протоны идэвхтэй 1 синглет сигнал илэрснийг метоксил бүлэгт оноолоо. Ийнхүу ${ }^{1} \mathrm{H}$ ПСР-ын спектрийн судалгааны дүнд 1 метоксил бүлэгтэй, 6 ароматик протонтэй, соронзон орны сул талбайд хэд хэдэн протон агуулсан нэгдэл байгааг урьдчилсан байдлаар тогтоолоо.

Цаашид тухайн бодисын нүүрстөрөгчийн атомын тоо тэдгээрийн халагдалтын зэргийг тогтоох зорилгоор ${ }^{13} \mathrm{C}$ ЦСР-ын спектрийг бүртгэхэд нийтдээ 16 нүүрстөрөгчийн атомын сигнал илрэв. $\delta 183.5,166,164,134.3,156,154,162.5$, 124, 105 с.х.-ийн хими шилжилтийн утганд 
илэрсэн 9 нүүрстөрөгчийн атомын сигналыг дөрөв халагдсан хэлбэрт өөрөөр хэлбэл соронзон орны харьцангуй сул талбайд илэрч байгаа нь тухайн нүүрстөрөгчийн атомууд устөрөгчийн атомтай холбогдоогүй эсвэл хүчилтөрөгчийн атомтай холбоотой байх магадлалтай гэж үзэв. Харин соронзон орны харьцангуй хүчтэй талбайд $\delta 60.8$ c.х.-т нэг сигнал илэрснийг метоксил бүлгийн нүүрстөрөгчийн атомд оноосон. $\delta$ 103, 97, 129.2 ба 108 с.х.-т 6 сигнал илэрснийг метилен бүлгийн нүүрстөрөгчийн атомуудад тус тус оноов. Эдгээрийн 4 нүүрстөрөгчийн атом нь 2-2-оороо давхацсан хэлбэртэй илрэв.

Ийнху ${ }^{13} \mathrm{C}$ ЦСР-ын спектрийн судалгааны дүнгээс тухайн бодис нь нийт 16 нүүрстөрөнчийн атом агуулсан түүний 8 нүүрстөрөгчийн атом нь дөрөв халагдсан, нэг метоксил, нэг карбонил бүлэг агуулсан нэгдэл байгаа нь батлагдав.

Улмаар Jm-1 бодисын устөрөгч болон нүүрстөрөгчийн атомуудын хамаарал, хэрхэн холбогдож байгааг тогтоох зорилгоор түүнийг MeOD-д уусгаж, Brucker Avance $600 \mathrm{MHz}$ багаж дээр хоёр хэмжээст HSQC спектрийг бүртгэв. Тухайн спектрийн дүнд тус бүр нэг протоны идэвхтэй $\delta 103$ c.х. ба $\delta 97$ с.х-ийн хими шилжилтийн утгад 2 нүүрстөрөгчийн атомын сигнал илэрснийг Н-3 ба Н-8 байрлал дахь метин бүлгийн сигналтай, $\delta 60.80 \quad$ c.х.-ийн нүүрстөрөгчийн атомын сигналыг Н-11 байрлал дахь метоксил бүлэгтэй, харин $\delta 183.5$ c.х.-т байгаа нэг нүурстөрөгчийн атомыг Н-4 байрлал дахь карбонил (-CO) бүлэгтэй, $\delta$ 103, 97, 129.2, 108 c.х.-т байгаа 6 нүүрстөрөгчийн атомын сигналыг Н-3, Н-8, Н-2', Н-5', Н-3', Н-6'байрлал дахь устөрөгчийн атомуудтай тус тус холбоотой байгааг тогтоов. Харин $\delta 166,164,134.3$, 156, 154, 105, 162.5, 124 с.х.-т бүртгэгдсэн 8 нүүрстөрөгчийн атомын сигналыг дөрөв халагдсан буюу ямарч устөрөгчийн атомтай холбоогүй болохыг тогтоов.

Jm-1 бодисын устөрөгчийн атомууд нь нэг, хоёр, гурван холбооны дараах нүүрстөрөгчийн атомуудтай хэрхэн холбогдсон бүтэц байгууламжтай байгааг тогтоох зорилгоор тухайн бодисыг МеОН-д уусгаж, Brucker Avance $600 \mathrm{MHz}$ багаж дээр хоёр хэмжээст НМВС спектрийг бүртгэж дүн шинжилгээ хийв. Ароматик муж дахь $\delta$ H-3 (1H, s) протон нь C-10, C-1', C-9; H-8 $(1 \mathrm{H}, \mathrm{s})$ протон нь C-10, C-6, C-5; H-2' $(2 \mathrm{H}, \mathrm{d}, \mathrm{J}=8.6$ Гц) протон нь C-3', C-4', C-2; H-6' (2H, d, J=8.6 Гц) протон нь C-1', C-4', C-2; H-3' (2H, d, J=8.6 Гц) протон нь C-1', C-4' ба Н-5' (2H, d, J=8.6 Гц) протон нь C-4', C-3', С-1' нүүрстөрөгчийн атомуудтай, харин соронзон орны харьцангуй хүчтэй талбайд илэрсэн Н-11(3H, s) протон нь С-6, C-7, C-5 нүүрстөрөгчийн атомуудтай тус тус алсын харилцан үйлчлэлтэй байгааг Зураг 1-д үзүүлэв.

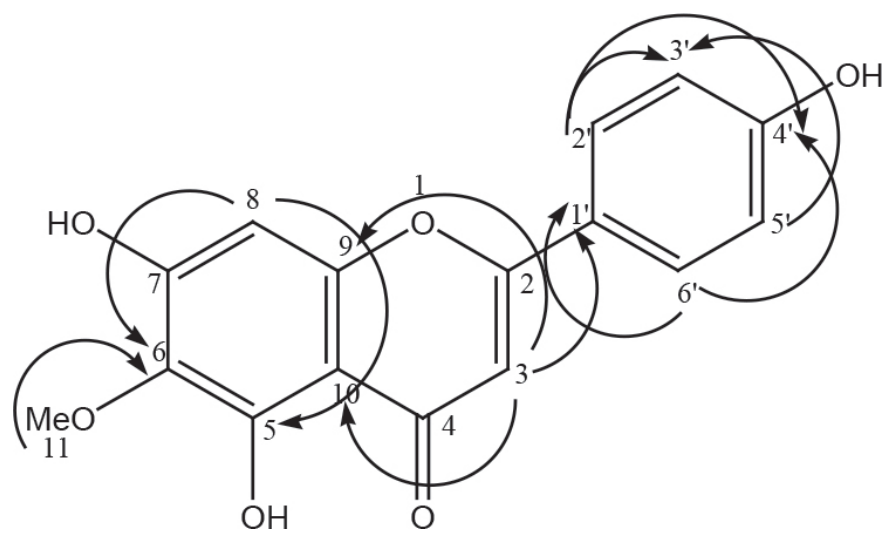

Зураг 1. Jm-1 бодисын НМВС спектр 
НМВC спектр нь тухайн нэгдлийн аль нэг байрлал дахь устөрөгчийн атом нь нэг, хоёр, гурван холбооны дараах нүүрстөрөгчийн атомуудтай хэрхэн харилцан үйлчлэлцэж байгааг тогтоодог.

Ийнхүу бид “Jm-1" бодисын бүтэц байгууламжийг ${ }^{1} \mathrm{H} П \mathrm{CP},{ }^{13} \mathrm{C}$ бахоёр хэмжээст (HSQC, HMBC) ЦСР-ын спектроскопийн судалгааны дүнд нарийвчилсан тайлал хийж тухайн бодис $\mathrm{C}_{16} \mathrm{H}_{12} \mathrm{O}_{6}$ ерөнхий томёотой, 300.25 молекул масстай, флавоны бүлэгт хамрагдах зургаан ароматик протон, нэг метоксил, нэг карбонил, гурван гидроксил бүлэг агуулсан 5, 7-дигидрокси-2-(4гидроксифенил)-6-метокси-4Н-хромен-4оне буюу хиспидулин (Hispidulin) хэмээх нэгдэл болохыг (Зураг 2) таньж тогтоов.<smiles>COc1c(O)cc2oc(-c3ccc(O)cc3)cc(=O)c2c1O</smiles>

Зураг 2. Хиспидулин (Hispidulin)

\section{2. Бактерийн антибиотик тэсвэрлэх чадварыг дарангуйлах идэвх (guorum sensing)}

Бид Монгол чоногоно (Jurinea бактерийн антибиотикт тэсвэрлэх чадварыг mongolica Maxim.) ургамлын газрын дарангуйлах идэвхийг Ахмедийн (Ahmed дээд хэсгийн зарим бүлэг ханд, усан et al., 1998) аргаар тодорхойлсон үр дүнг үлдэгдэл болон нийлбэр алкалоидын Хүснэг 2ээр үзүүлэв.

ХУснэгт 2. Монгол чоногоно ургамлын зарим бүлэг ханд, усан үлдэгдэл, нийлбэр алкалоидын бактерийн антибиотик тэсвэрлэх чадварыг дарангуйлах идэвх, мм

\begin{tabular}{|l|l|l|l|l|l|l|}
\hline$№$ & Дээж & Тун & Үр дүн & Үр дүн & Дундаж \\
\hline \multicolumn{2}{|l|}{ Монгол чоногоно } & 30 мг/мл & - & - & - \\
\hline 1 & Петролеиний эфирийн бүлэг ханд & 30 мг/мл & 14.0 & 17.0 & $15.5 \pm 2.12$ \\
\hline 2 & Хлороформын бүлэг ханд & 30 мг/мл & 9.0 & 15.0 & $12 \pm 4.24$ \\
\hline 3 & Этилацетатын бүлэг ханд & 30 мг/мл & - & - & - \\
\hline 4 & н-бутанолын бүлэг ханд & 30 мг/мл & - & - & - \\
\hline 5 & Усан үлдэгдэл & 30 мг/мл & 10.0 & 10.0 & $10 \pm 0.0$ \\
\hline 6 & Нийлбэр алкалоид & & & - идэвхгй \\
\hline
\end{tabular}

Судалгааны дүнд тухайн ургамлын петролейний эфир, н-бутанолын бүлэг ханд болон усан үлдэгдэл нь 30 мг/мл тундаа бактерийн антибиотик тэсвэрлэх чадварыг дарангуйлах идэвхгүй байна. Харин хлороформ, этилацетатын бүлэг ханд болон нийлбэр алкалоид нь 30 мг/мл тундаа 15.5 \pm 2.12 мм, $12 \pm 4.24$ мм, $10 \pm 0.0$ мм тус тус хэмжээтэй quorum sensing механизмыг дарангуйлах идэвхтэй байна. Судалгааны явцад микроорганизмын нягтаршил их байх тусам эс хоорондын харилцан үйлчлэл - 19 - 
нэмэгдэх замаар үүссэн биофильм нь микроорганизмын эмэнд тэсвэртэй чанарыг нэмэгдүүлдэг ба энэ процессийг quorum sensing механизм зохицуулдаг байна.
Өөрөөр хэлбэл Quorum sensing механизмыг дарангуйлснаар микроорганизмын эмэнд тэсвэртэй шинж чанарыг нь бууруулах боломжтой юм ${ }^{16,17}$.

\section{3. Бактерийн эсрэг идэвх}

Монгол чоногоно ургамлын зарим бүлэг ханд, усан үлдэгдэл болон нийлбэр алкалоидын бактерийн эсрэг идэвхийн судалгааг 6 тест омгийг ашиглан, цаасан дискийн аргаар тодорхойлсон үр дүнг Хүснэгт 3-т үзүүлэв.

Хүснэгт 3. Монгол чоногоно ургамльн зарим бүлэг ханд, усан үлдэгдэл болон нийлбэр алкалоидын бактерийн эсрэг идэвх, мм

\begin{tabular}{|c|c|c|c|c|c|c|c|c|}
\hline № & Дээжийн нэр & Тун & 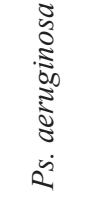 & $\begin{array}{l}\ddot{\Xi} \\
0 \\
\dot{0}\end{array}$ & 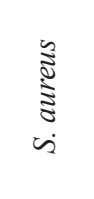 & 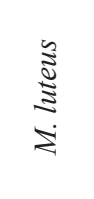 & 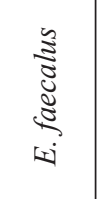 & 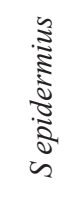 \\
\hline \multicolumn{9}{|c|}{ Монгол чоногоно } \\
\hline 1 & Петролейний эфирийн бүлэг ханд & $10 \mathrm{Mг} / \mathrm{мл}$ & - & - & - & - & - & - \\
\hline 2 & Хлороформын бүлэг ханд & 10мг/мл & - & - & 11.4 & 13.12 & - & 15.16 \\
\hline 3 & Этилацетатын бүлэг ханд & 10мг/мл & - & - & - & - & - & - \\
\hline 4 & н-бутанолын бүлэг ханд & 10мг/мл & - & - & - & - & - & - \\
\hline 5 & Усан үлдэгдэл & 10мг/мл & - & - & - & - & - & - \\
\hline \multirow[t]{2}{*}{6} & Нийлбэр алкалоид & $10 \mathrm{Mг} / \mathrm{M}$ & - & - & 10.9 & 9.9 & - & - \\
\hline & Канамицин & & 14.12 & 14.14 & 18.17 & 15.16 & 16.17 & 19.20 \\
\hline
\end{tabular}

Судалгааны дүнгээс үзэхэд тухайн ургамлын петролейний эфир, этилацетат, н-бутанолын бүлэг ханд болон усан үлдэгдэл нь 10 мг/мл тундаa 6 бактерийн омгийн ургалтыг дарангуйлах идэвх үзүүлээгүй байна. Мөн хлороформын бүлэг ханд 10 мг/мл тундаа Ps. aeruginosa, E. faecalus, E. coli бактерийн ургалтыг дарангуйлаагүй бол $S$. aureus, M. luteus, $S$ epidermius бактерийн ургалтыг 11.4 мм, 13.12 мм, 15.16 мм хэмжээтэй тус тус дарангуйлсан байна. Нийлбэр алкалоид нь 10 мг/мл тундаа Ps. aeruginosa, E. faecalus, E. coli, $S$ epidermius бактерийн ургалтыг дарангуйлаагүй боловч, грам эерэг $S$. aureus, M. luteus бактерийн ургалтыг 10.9 мм, 9.9 мм хэмжээтэй тус тус дарангуйлсан идэвх үзүүлэв.

\section{4. Мутагеныг дарангуйлах идэвх}

Монгол чоногоно ургамлын зарим бүлэг ханд, усан үлдэгдэл, нийлбэр алкалоидын мутагенийг дарангуйлах идэвхийн судалгааг Амесийн сорилоор (Ames et. al.,1973) тодорхойлж, дүнг Хүснэгт 4-д үзүүлэв. 
Хүснэгт 4. Монгол чоногоно ургамльн зарим бүлэг ханд, усан үлдэгдэл нийлбэр алкалоидын мутагеныг дарангуйлах идэвх, \%

\begin{tabular}{|c|c|c|c|c|c|c|}
\hline № & Дээж & Тун & 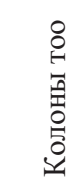 & $\begin{array}{l}8 \\
8 \\
0 \\
0 \\
0 \\
0 \\
0\end{array}$ & 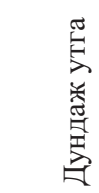 & 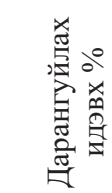 \\
\hline \multicolumn{7}{|c|}{ Монгол чоногоно } \\
\hline 1 & Петролеиний эфирийн бүлэг ханд & $1 \mathrm{мг} / \mathrm{мл}$ & 250 & 204 & 227 & $8 \%$ \\
\hline 2 & Хлороформын бүлэг ханд & $1 \mathrm{мг/мл}$ & 98 & - & - & $62 \%$ \\
\hline 3 & Этилацетатын бүлэг ханд & 1 мг/мл & 137 & - & - & $46 \%$ \\
\hline 4 & н-бутанолын бүлэг ханд & $1 \mathrm{мг/мл}$ & 244 & 215 & 229.5 & $7 \%$ \\
\hline 5 & Усан үлдэгдэл & $1 \mathrm{мг/мл}$ & 142 & - & - & $44 \%$ \\
\hline 6 & Нийлбэр алкалоид & $1 \mathrm{мг/мл}$ & 105 & - & - & $59 \%$ \\
\hline 7 & Хяналт & & 251 & 246 & 248.5 & \\
\hline
\end{tabular}
идэвхгүй

Монгол чоногоно ургамлын хлороформ, этилацетат, н-бутанолын бүлэг ханд, усан үлдэгдэл болон нийлбэр алкалоидын мутангеныг дарангуйлах идэвх нь 1 мг/ мл тундаа $62 \%, 46 \%, 77 \%, 59 \%$ тус тус хэмжээтэй буюу харьцангуй сайн байна.
Харин петролейний эфир, н-бутанолын бүлэг хандны мутангенийг дарангуйлах идэвх нь ижил тундаа харьцангуй бага буюу $8 \%, 7 \%$ хэмжээтэй байгааг нь сулавтар гэж үзэж болно.

\section{5. Метанолын хандны нийлбэр фенолт нэгдэл ба антиоксидант идэвх}

Тухайн ургамлын метанолын хандны нийлбэр фенолт нэгдлийг Folin- Ciocalteauын, антиоксидант идэвхийг ABTS ба DPPH аргуудаар тус тус харьцуулан судалсан дүнг 5-р хүснэгтэнд үзүүлэв.

Хүснэгт 5. Монгол чоногоно ургамлын метанолын хандны нийт фенолт нэгдэл болон антиохидант идэвхийг галльн хүчилтэй эквивалент тооиоолсон үр дүн,

\begin{tabular}{|c|l|c|}
\hline № & \multicolumn{1}{|c|}{} \\
\hline 1 & Нийлбэр фенолт нэгдэл, (ТРС) & $14,1 \pm 0,3$ \\
\hline 2 & Антиоксидант идэвх, (АВТS) & $3,6 \pm 0,3$ \\
\hline 3 & Антиоксидант идэвх, (DPPH) & $0.3 \pm 0.1$ \\
\hline
\end{tabular}

Метанолын хандны нийлбэр фенолт нэгдлийн агууламж нь $14,1 \pm 0,3 \quad \mu г /$ мл, харин метанолын хандны чөлөөт радикалыг дарангуйлах идэвх нь $3,6 \pm 0,3 \mu г$ мл
(ABTS), $1,3 \pm 0,1 \mu$ г/мл (DPPH) тус тус байгаа нь харьцангуй өндөр антиоксидант идэвхтэйд тооцогдоно. 


\section{Дүгнэлт}

- $\quad$ Тухайн зүйл ургамлын газрын дээд хэсгийн этилацетатын бүлэг ханднаас анх удаа олдсон хиспидулин бодисыг химийн цэвэр төлөв байдлаар ялгаж молекулын бүтэц байгууламжийг ${ }^{1} \mathrm{H}$ ПСР, ${ }^{13} \mathrm{C}$ болон хоёр хэмжээст ЦСР-ын спектроскопын аргаар таньж тодорхойлов.

- $\quad$ Монгол чоногоно ургамлын зарим бүлэг ханд, усан үлдэгдэл болон нийлбэр алкалоидын бактерийн антибиотик тэсвэрлэх чадварыг дарангуйлах идэвх, бактерийн эсрэг идэвх, мутацийн эсрэг идэвх, чөлөөт радикалыг дарангуйлах идэвхийг тогтоов.

- Тухайн ургамлын метанолын хандны нийлбэр фенолт нэгдлийн агуулга нь $14,1 \pm 0,3 \mu г$ млл байна.

\section{Ашигласан бүтээлийн жагсаалт}

1. В.И.Грубов, (2008), Монголын гуурст ургамльг таних бичиг, Ган принт компани, УБ, 314.

2. Hulya Oztuk, Ufuk Kolak and Ciler Meric (2011), Antioxidant, Anticholinesterase and Antibacterial Activities of Jurinea consanguinea DC. Rec. Nat. Prod, p. 43-51.

3. A. Danin, P. H. Davis (1975), Jurinea Cass. In flora of Turkey and the East Aegean Islands, Vol. 5, Davis PH (ed), University Press: Edinburg, p. 439-440 and 442-443.

4. B. Dogan, A. Duran, E. Martin and E. E. Hakki (2010), Jurinea turcica (Asteraceae), a new species from North-West Anatolia, Turkey, Biologia 65, p. 28-32.

5. A. Rustaiyan, A. Nikneyad et al., (1981), Naturally occurring terpen derivatives. A guaianolide from Jurinea carduiformis, Phytochemistry 20, p. 1154.

6. M. Todorova and I. Ognyanov (1984), Sesquiterpen lactones in leaves of Jurinea albicaulis, Planta Med. 50, p. 452-453.

7. S. K. Zakirov, S. Z. Kasymo and G. P. Sodyakin (1975), Sesquiterpene lactones from Jurinea maxima, Kim, Prir. Soedin. 5, p. 656-657.

8. A. Rustaiyan and M. Ganji (1988), Germacranolides from Jurinea eriobasis, Phytochemistry 27, p. 2991-2992.

9. K. L. Nikolajchak and C. R. Smith (1967), Pentacyclic triterpenes of Jurinea anatolica and Jurinea consanguinea fruit, Lipids 2, p. 127-132.

10. M. Todorova and I. Ognyanov (1996), Pentacyclic triterpenes in roots of J. albicaulis, Fitoterapia 67, p.383.

11. S. Kirbag, F. Zengin, M. Kursat (2009), Antimicribail activities of extracts of some plants Pak. J. Bot. 41, p. 2067-2070.

12. K. C. Sekar, and S. K. Srivastava (2005), New reports on aphrodisiac plants from Pin Valley National Park, Himachal Pradesh, Ethnobotany 17, p. 189-190.

13. Ahkmed I., Mehmood Z., and Muhammad F. (1998), Screening of some Indian medicinal plants for their antimicrobial properties. J. Ethnopharmocol 62, p. 183-193.

14. A. W. Bauer, W. M. M. Kirby et. al., (1966), Antibiotic susceptibility testing by a standardized single disk method, The American Journal of clinical Pathology, Vol. 45, 4, p. 493-496.

15. Perez, C., Pauli, M., Bazerque, P., (1990), An antibiotic assay by agar-well diffusion method. Acta Biologiae et Medicine Experimentalis , 15, p. 113-115.

16. Mc Clean et al., (1997), Qourum sensing and Chromobacterium violaceum: exploitation of violaceim production of $\mathrm{N}$-acylhomoserine lactones, Bicrobiology, 143 (Pt12), p. 37033711 .

17. Hall-Stoodley L, Costerton JW, Stoodley P (2004), "Bacterial biofilms: From the natural environment to infectious diseases". Nature Reviews Microbiology 2 (2): 95-108.

18. Ames B. N., J. McCann, E. Yamasaki (1975), Methods for detecting carcinogens with the Salmonella/mammalian-microsome mutagenicity test. Mutation Research 31, p. 347-364. 
19. Sebastian Tejs (2008), The Ames test: a methodological short review, Environmental biotechnology, 4 (1), p. 7-14.

20. Spellberg B, Powers J.H, Brass E.P, Miller L.G, Edwards J.E, (2004), Trends in1286 antimicrobial drug development: implications for the future. Clin Infect Dis 38, p.12791286.

21. Singleton V, Orthofer R, Lamuela-Raventos R, (1999), Analysis of total phenols and other oxidation substrates and antioxidants by means of Folin-Ciocalteu reagent, Ed: Packer L, Oxidants and antioxidants, part A methods in enzimology, Vol 299, pp 152-178, Academic Press, New York.

22. Dorota Martysiak-Zurowska, Weronika Wenta (2012), A comparision of ABTS and DPPH methods for assessing the total antioxidant capacity of human milk, Acta Sci. Pol., Technol. Aliment. 11(1), p.83-89.

23. Michael Antolovich, Paul D. Prenzler, Emilios Patsalides et al., (2001), Methods for testing antioxidant activity, School of Science and Technology, Charles Sturt University, Wagga, Australia. 


\title{
THE PHYTOCHEMICAL AND BIOLOGICAL ACTIVITY STUDY OF JURINEA MONGOLICA MAXIM. GROWING IN MONGOLIA
}

\author{
M. Dumaa", T. Solongo ${ }^{1}$, M. Bolortuya ${ }^{1}$, G. Chunsriimyatav ${ }^{1,2}$, \\ Margit Gruner ${ }^{2}$, Hans-Jaochim Knoelker ${ }^{2}$, D. Regdel ${ }^{1}$ \\ 1. Institute of Chemistry and Chemical Technology, MAS, Mongolia \\ 2. Department of Chemical Technology, Dresden University, Germany
}

\begin{abstract}
Hispidulin was isolated from ethyl acetate fraction of aerial parts (APs) of Jurinea mongolica Maxim. growing in Mongolia for the first time. Its molecular structure was elucidated by using ${ }^{1} \mathrm{H},{ }^{13} \mathrm{C}$ and 2D NMR spectroscopic methods.

In addition, anti-quorum sensing (QS) activity of the total alkaloids, chloroform and ethyl acetate fractions from APs of $J$. mongolica were evaluated $10.0 \pm 0.0 \mathrm{MM}, 15.5 \pm 2.1 \mathrm{MM}, 12.0$ $\pm 4.24 \mathrm{Mm}$ at $30 \mathrm{mg} / \mathrm{ml}$ dose; inhibition zone sizes against $S$. aureus, M. luteus, Sh. epidermius strains of chloroform fraction at $10 \mathrm{mg} / \mathrm{ml}$ dose were $11.4 \mathrm{MM}, 13.12 \mathrm{MM}, 15.16 \mathrm{MM}$, respectively.

Furthermore, anti-mutagenic activity of the petroleum ether, chloroform, ethyl acetate, nbuthanolic extract, water residue and total alkaloids from APs of J. mongolica were evaluated $8 \%, 62 \%, 46 \%, 7 \%, 44 \%, 59 \%$, respectively. A total phenolic compounds of methanol extract

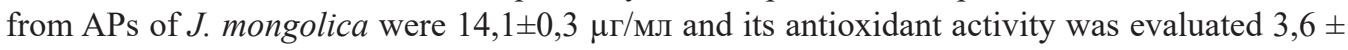
$0,3 \mu г /$ мл (ABTS) and 1,3 $\pm 0,1 \mu г /$ мл (DPPH), respectively.
\end{abstract}

